\title{
Gender Division of Labour and Women's Decision-Making Power in Rural Households in Cameroon
}

\author{
Fondo Sikod*
}

\begin{abstract}
In most rural areas of Cameroon, women are incorporating a market-oriented dimension to their farming activities. This is an improvement from years before when food crop farming was almost exclusively for household consumption. This additional focus on food crop farming is mainly as a result of the need to supplement household incomes following the drop in salaries which came as a result of the economic crisis Cameroon and many African countries have been facing since the 1980s. Nominal incomes for salary earners in Cameroon, mostly men, were slashed by over 60 per cent in the early 1990s (Tchoungui et al., 1995). The agricultural sector was not spared either. Most of Cameroon's foreign earnings come from agricultural commodities - cocoa, coffee, cotton, whose production is largely in small-holdings owned mostly by men. In the 1980s, world prices for these commodities collapsed, and of course, the incomes of the small-holders dropped drastically. The burden of making up for this shortfall within households was placed on the backs of women. Considering that decision-making seems to be based on, among other factors, economic power, income earnings is likely to confer a certain degree of decision-making power on women (Ngome 2003). This paper looks at how change in the gender division of labour impacts women's decision-making power, and whether the traditional division of labour, which gives women very little access to labour-augmenting resources, leads to an inefficient allocation of resources that retard development.
\end{abstract}

\section{Résumé}

Dans la plupart des zones rurales du Cameroun, les femmes ajoutent une dimension axée sur le marché à leurs activités agricoles. Cela constitue une amélioration par rapport aux années précédentes pendant lesquelles l'agriculture vivrière

* University of Yaoundé II, Yaoundé, Cameroon. Email: fsikod2002@yahoo.com 
était presque exclusivement destinée à la consommation des ménages. Ce nouvel éclairage sur l'agriculture vivrière résulte essentiellement de la crise économique frappant le Cameroun et plusieurs autres pays africains depuis les années 1980. Des coupes sombres ont diminué les salaires nominaux des Camerounais de plus de soixante pour cent au début des années 1990 (Tchoungui et al., 1995). Les hommes constituent la majorité des salariés. Le secteur agricole n’a pas été épargné non plus. La plupart des recettes en devises du Cameroun proviennent des produits agricoles de base (cacao, café, coton). La production de ces denrées se fait principalement dans les petites exploitations détenues en majorité par des hommes. Dans les années 1980, l'effondrement des cours de ces produits sur les marchés mondiaux a évidemment entraîné une dégringolade des revenus des petits exploitants. La lourde charge de contrebalancer ce déficit a été déposée sur les épaules des femmes. Etant donné que la prise de décision semble reposer entre autres facteurs sur le pouvoir économique, gagner des revenus confère vraisemblablement aux femmes un certain degré de pouvoir décisionnel (Ngome 2003). Le changement intervenu en matière de division du travail est l'une des variables influant sur la prise de décision. Il s’agit ici de se pencher sur la manière dont la division sexospécifique du travail influe sur le pouvoir de décision des femmes, et de voir si la division traditionnelle du travail conduit à une affectation inefficace qui retarde le développement. Dans le contexte traditionnel, les femmes ont très peu accès aux ressources augmentées par le travail.

\section{Introduction}

In Cameroon, women make up more than 50 per cent of the population, but do not usually have a say in major decisions that are taken, not only in the households, but also at the national level: decisions that affect their lives and their relations with men. These decisions shape the way the nation functions. Change in the division of labour is one of the variables which influences decision-making. For example, activities that confer more incomeearning power on women tend to increase their participation in decision-making in the household (Ngome 2003).This paper looks at how gender division of labour impacts women's decision-making power, and whether the traditional division of labour leads to inefficient allocation of resources that retard development. The types of activities members of households are involved in, impacts on their contribution to household welfare and decision-making abilities.

In this paper, we use the international trade theory of comparative advantage to examine the household division of labour and the implications for decision-making. Basically this theory states that a producer produces that commodity in which he/she has the greatest advantage. In the household context, members of the household should get involved in those activities in which they have a comparative advantage. In this way, household welfare 
can be maximised. Unfortunately, gains from this type of a relationship can be uneven because of the way activities may be perceived: some activities are perceived to have more value and consequently to confer more power than others. The gains may also be uneven because of the socio-cultural endowments that ascribe to the sexes types of responsibilities and activities with differing powers. Most of the information used for the analyses in this paper come from two studies 'The Impact of the Chad-Cameroon Oil Pipeline Operations on Gender Relations, Land Resources and Community Livelihood' by Endeley and Sikod (2005), and 'Gender Division of Labour and Women's Decision-Making Power in Rural Households: The Case of Mbalangi, Ediki and Mabonji Villages of Meme Division' by Njolle Ngome (2003).

\section{Factors influencing the division of labour}

In the household, men and women are involved in different activities to ensure the availability of goods and services for family consumption and well-being. Although these activities may be different, they have a social connectedness. An intricate and changing relationship of cooperation and exchange between men and women exists within the household, which is potentially conflictual. Despite the conflictual nature of this relationship, the gender division of labour in households is the main economic strategy used to meet family basic needs for shelter, food, health, procreation and education. And yet, the nature of this division of labour is one that constrains development.

A number of factors are responsible for the gender division of labour today: some are gender-neutral and others are gender-biased. For example, child care, household care (cooking, cleaning, fetching wood and water, etc.) are activities ascribed to women that are gender-biased. They have come about as a result of socio-cultural socialisation, and not necessarily from ability based on comparative advantage. A gender-neutral process is one where in a household, comparative advantage and the maximisation of household welfare is used to determine which partner does what.

Other variables responsible for the division of labour, and more common in most rural societies, have to do with the allocation of activities to individuals based on kinship, age, descent, culture, education, status and marriage. However, what is usually glaring is the division of market and non-market activities along gender lines. Market activities are tradable activities through interactions between consumers and producers, leading to the monetary valuation of activities. These activities may be formal or informal. This division leading to monetary incomes is particularly important because money income confers power on people. Thus, in a household where women com- 
mand some money income, it gives them some say in decision-making in their homes (Ngome 2003).

Education is increasingly becoming a major factor enabling women to break down barriers to some socialisation factors giving rise to the division of household labour. The more educated a woman is, the more likely it is she is going to venture into spheres traditionally considered male areas. These factors have important implications for women's empowerment and their ability to contribute to the overall development of not only the household, but also the nation.

As in most of rural Africa, agriculture is the main occupation of nearly everybody in Cameroon, and the source of livelihood. Here, there is strong division of farming labour by sex and by type of crops. The men farm what has been traditionally known as cash crops - cocoa, coffee - while the women farm what the family consumes, hence the appellation, subsistence farming. Although what the woman farms is crucial to the survival of the household, only the excess is sold, thus giving the woman limited control over the ability to buy what she does not produce.

Today, in most rural areas of Cameroon, women are including a marketoriented dimension to their farming activities. This is an improvement from years before when food crop farming was almost exclusively for household consumption. This additional focus on food crop farming is mainly as a result of the need to supplement household incomes following the drop in salaries which came as a result of the economic crisis Cameroon and many African countries have been facing since the 1980s. Nominal incomes for salary earners in Cameroon were slashed by over 60 per cent in the early 1990s (Tchoungui et al., 1995). Most of the salary earners are men. The agricultural sector was not spared either. Most of Cameroon's foreign earnings come from agricultural commodities - cocoa, coffee, cotton. The production of these commodities is on small-holdings owned mostly by men. In the 1980s, world prices for these commodities collapsed, and of course, the incomes of the small-holders dropped drastically. The burden of making up for this shortfall within households was placed on the backs of women, who were therefore obliged to produce not just for household consumption, but also for the market.

\section{Division of household activities and decision-making}

Decision-making within households has to do with bargaining, and this bargaining depends on the endowments of the parties. Incidentally, these endowments are not necessarily natural. Some are natural, but most are a human product. These have often led to allocation inefficiencies, especially 
Figure 1: Division of Tasks by Sex

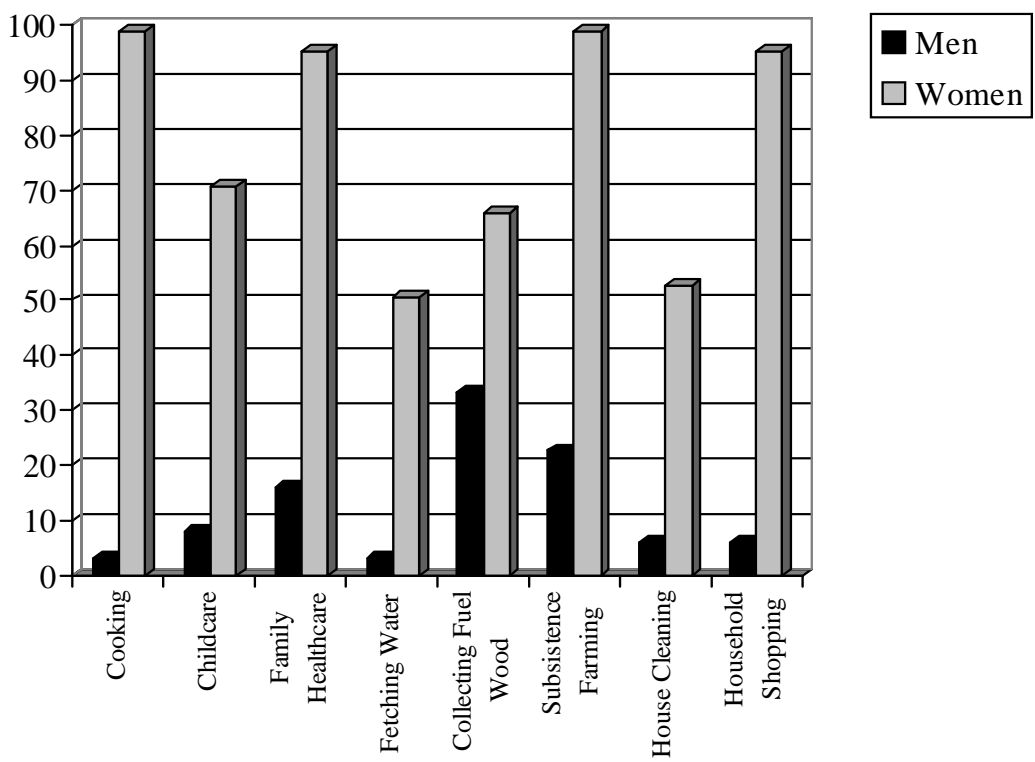

Source: Ngome 2003

in labour resources and other resources that are labour enhancing, that impact on development negatively. Women are not given the opportunity to compete with men for certain jobs, even if women may do the jobs better than some men. Because of socio-cultural socialisation and biology women in most societies have tended to dominate non-market activities. (Figure 1) In Cameroon the traditional division of labour most often situates women in roles based on providing emotional support and maintenance, while men are primarily responsible for economic support and contact with the world outside the home. Women's participation is in activities such as cooking, fetching water, and food processing, all of which are outside the cash economy and concentrated around the household.

Unfortunately, most women do not consider their chores as 'work' and thereby do not rate these activities as entitled to any form of recognition. This is a perception most often reflected in the inequalities that women suffer, and reveals why it is unlikely that they will be active in decision-making. What is interesting is that the state has tended to sanction this situation.

Changing trends caused by education, growing awareness of the blatant inequalities and the need to correct them, and the economic situation, are 
reshaping the decision-making process within households. This is a process that is conflictual, as the man sees his dominant decision-making powers waning, and the woman is discovering that she is being empowered as she gets more and more into the decision-making position. While in some homes this changing process is through negotiation, in others, it is through confrontation. Many women experience decision-making problems as a result of the inequalities in the perception of the gains from the activities carried out by household members.

A woman's ability to bargain in the household is usually augmented by the increase in her income, which leads to greater equity in the dispensation of household resources. Ngome (2003), found in her study that 77 per cent of the men and 73 per cent of the women interviewed said the lack of income affects the man's decision-making power. She also found that 98 per cent of the women and 83 per cent of the men believe once a woman is in a position to meet the needs of the household, she obtains more respect from her husband, while the lack of income meant women were subjected to insults, leading to lack of peace in the home.

But the reward system is unfair, and consequently the areas of decisionmaking are biased in favour of the man (Table 2). An analysis of men's and women's time allocation captures the interdependence between the market and non-market or household economies. Women work longer hours than men. Much of women's productive work is unrecorded and not included in the System of National Accounts. Children are closely integrated into household production systems, and the patterns that disadvantage girl-children begin very early. Poor households need their children's labour, sometimes in ways that also disadvantage boys. Domestic chores, notably fetching water and fuel wood, are one of the factors limiting girl's access to schooling and consequently, the woman's inability to participate in certain economic activities.

The transport sector also illustrates the interdependence between the market and the household economies, and the associated time problem for women. The gender division of labour leaves women with a much heavier transport task in rural areas. They have to transport the crops from the farms, they have to travel to fetch water and fuel wood, and so on.

Women perform about 90 per cent of the work of processing food crops and providing household water and fuel wood, 80 per cent of the work of food storage and transport from farm to the village, 90 per cent of the work of hoeing and weeding, and 60 per cent of the work of harvesting and marketing (Ngome 2003). 
Figure 2. Areas of decision-making by gender

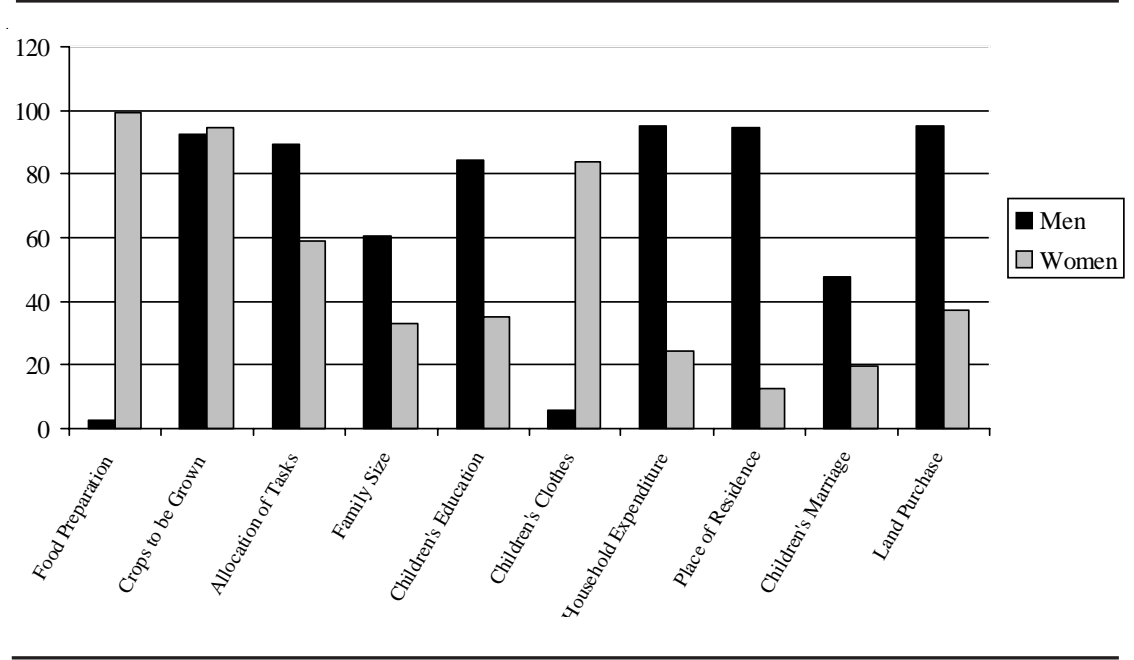

Source: Ngome 2003.

Reproductive work involves the care and maintenance of the household and its members including bearing and caring for children, food preparation, water and fuel collection, shopping, housekeeping and family care. Reproductive work is crucial to human survival and the maintenance and reproduction of the labour force, yet it is seldom considered 'real work'. In poor countries, reproductive work is, for the most part, labour-intensive, and time-consuming. It is almost always the responsibility of women and girls. 'Real work' is seen as productive work, which involves the production of goods and services for consumption and trade (farming, fishing, employment and self-employment). When people are asked what they do, the response is most often related to productive work, especially work which is paid or generates income (Moser and Levy 1986).

The majority of women are small-holders producing on a very small scale and relatively unaffected by developments in the use of improved tools and seeds, and yields are highly determined by the weather. Their involvement in agricultural production is often a struggle to first provide enough for their households. This does not encourage savings against future consumption, against economic shocks and other hazards. 


\section{Factors responsible for the changing trends in decision-making in the households}

We can classify the factors responsible for the changing trends into three broad categories:

(i) Changes in the economic situation;

(ii) Education; and

(iii) Democracy and Women’s Rights.

Perhaps the most important change has come as a result of the economic crisis as discussed above. As the economy has continued to falter, the subsistence activities of women have gradually been transformed into market activities, giving them more economic power, and consequently the right to participate in decision-making in the home. In economic life and employment, women represented 37.5 per cent of the active population in 1993: they were mostly found in agriculture. This is of course based on a very narrow definition of the workload of women (Kabeer 2003). It obviously does not include the reproductive work of women.

Micro-level analyses portray a picture of gender-based asset inequality acting as a constraint to growth and poverty reduction. Women face disadvantages compared with men in accessing the basic assets and resources needed to participate fully in realising their growth potential. These genderbased differences affect supply response, resource allocation within households, and labour productivity. The agricultural growth that is not achieved because of gender inequality is not marginal to the needs of the country, as it affects not only food security and well-being, but also contributes to greater vulnerability, and further reinforces risk-aversion.

In education, girls do not have the same access as boys. In Cameroon, the girl/boy ratio in primary education dropped from 85 per cent in 1989/90 to 82.9 per cent in 1997/98: in secondary education, the ratio rose from 82.1 per cent in 1994/95 to 85.6 per cent in 1998/99. These ratios varied greatly from one region to another: the higher the level of education the wider the gap between the sexes.

Vulnerability refers to defencelessness, insecurity and exposure to risk. It is a function of assets: the more assets people have, the less vulnerable they are. An awareness of the diverse nature of assets, and their hierarchy, is essential for meaningful policy action. Women and children are more vulnerable because tradition gives them less decision-making power and less control over assets than men, while at the same time their opportunities to engage in remunerative activities, and therefore to acquire their own assets, are more limited. 


\section{Factors responsible for continuing the status quo: asset inequality}

A major reason why there is such inequality is because of the asset inequality that we discuss below.

\section{(a) Human capital}

Education in Cameroon is a double-edged sword: it makes it possible for women to get out of their traditional roles through engaging in activities hitherto reserved for men. There is however, a gender gap in the number of girls and boys attending school at all levels, which tends to foster the divide. These vary greatly according to geographic locations, with the gap widening in the rural areas, and where certain religious and cultural structures are very strong.

Table 1: Girl/Boy Ratio in Primary School (\%)

\begin{tabular}{llll}
\hline Province & 1990 & 2000 & $\begin{array}{c}\text { Literacy Rate, } \\
\text { Young Women }\end{array}$ \\
\hline Adamawa & 64 & 71 & 46.3 \\
Centre & 95 & 95 & 96.6 \\
East & 84 & 84 & 73.3 \\
Far North & 53 & 60 & 26.5 \\
Littoral & 96 & 97 & 96.8 \\
North & 56 & 59 & 31.4 \\
North West & 88 & 92 & 91.3 \\
West & 96 & 95 & 96.5 \\
South & 91 & 93 & 98.4 \\
South West & 95 & 96 & 93.9 \\
Cameroon & 84 & 83 & 77.2 \\
\hline
\end{tabular}

Source: UNDP, Yaoundé (2003).

Table 1 shows the girl/boy ratio in various regions of Cameroon. For the nation, there has been a slight drop - 84 to 83 per cent - from 1990 to 2000 . The literacy rate for young women for the nation is just over 77 per cent, varying from a low of just over 26 per cent in the rural predominantly Muslim north to a high of over 96 per cent in the urban areas. At the socio- 
cultural level, some parents see no advantage in sending their children to school at the risk of endangering their faith when they themselves can teach the girls rural work and initiate them into their future responsibilities as mothers. This is typically the perspective in the Muslim regions of the country.

At the economic level, the poverty situation in households with scarce means encourages parents to enrol boys rather than girls in school because girls are destined to marry and leave the family. Also, girls tend to do most of the household chores like helping their mothers to cook, fetching water and fuel wood, and baby sitting and home cleaning. They also work on the farm with their mothers.

\section{(b) Direct productive assets}

Land. This is the most important resource for rural communities. Having access rights to land and other land-based resources is a crucial factor determining how people will ensure their basic livelihood. The vast majority of the population and all of the rural population rely on land and land-based resources for their livelihoods. An enormous variety of rights to natural resources are found in Cameroon. These rights are firmly embedded in complex socio-economic, cultural, and political structures. Thus, tenure defines who has access to what parcel of land and/or resources, for how long, and for what purpose. It applies in the same way to forest areas to ensure that land and forest use patterns are productive and sustainable. This process affects men and women directly. Quite often women are affected more directly and differently than men by environmental degradation as a result of their reproductive and productive roles. Women constitute the backbone and mainstay of the rural economy through their activities in agriculture and informal sector activities. They make up over 60 per cent of those who exploit natural resources - farming, harvesting NTFPs, collecting fuel wood, etc. Unfortunately, in spite of their number (approximately 51 per cent of the population) the institutional arrangements have made it difficult for them to gain access to land. Although the laws may appear to be gender-neutral, they are not. It is difficult for a woman to establish a land title because of the complex and long procedures involved, and more especially the bias they face from men. The ability of women to own land is further aggravated by the customs and traditions of the various tribes. In most areas of Cameroon, the woman is seen as the property of some other person (the man) who will collect her by way of marriage. In these areas, the customary justification of this fact is that 'property cannot own property'.

The Empowerment Approach to gender analysis recognises the need for women to have equal control over the distribution of benefits as men, without either sex being dominated. In the study by Endeley and Sikod (2005), in 
most of the communities studied over 78 per cent of the women interviewed said they had only use rights over land and could not dispose of it. As concerns access and control of forest resources, women's rights are exercised only within the existing traditional or indigenous tenure systems.

Table 2: How Women Acquire Land

\begin{tabular}{|c|c|c|c|c|}
\hline & \multicolumn{4}{|c|}{ Responses } \\
\hline & Married & Single & Divorced & Widowed \\
\hline Husband's Land & $\mathrm{X}$ & & $\mathrm{X}$ & \\
\hline $\begin{array}{l}\text { Father's or } \\
\text { husband's land }\end{array}$ & $\mathrm{X}$ & $\mathrm{X}$ & & \\
\hline Father's land only & & $\mathrm{X}$ & $\mathrm{X}$ & \\
\hline Purchase & & $\mathrm{X}$ & $\mathrm{X}$ & \\
\hline
\end{tabular}

Source: Endeley and Sikod (2005).

The most common way for women to acquire land is through their husband. They can also acquire land through their father (for single, divorced or widowed women), or through purchase (Table 2).

Labour. Men and women have different access to paid labour, and labour scarcity limits women's farming activity. Labour remuneration also differs along gender lines, as the total income share received by men is over twice the share received by women. Endeley and Sikod (2005) found that even though the same amount of effort was put into producing various crops, men earned far more than women because of the crops they cultivated. Women produce crops to sustain the household, and the excess is sold in local markets. Men produce what is generally called cash crops, because they are produced specifically for the market.

Like any other African household, the Cameroon household is a social institution for mobilising labour, where there are strong differences between household members in their social command over labour that are directly related to their position in the household hierarchy. Men tend to be heads of household, and so household labour is quite often manipulated by them to the detriment of the woman. It is also interesting to consider the external perception of household labour. Endeley and Sikod found in their study of the Chad-Cameroon pipeline project that women were not hired to do the jobs men were doing, like digging trenches, laying pipes, driving trucks and tractors, etc.: rather women were hired as house help - cleaning, cooking, etc. - jobs that command lower pay. 
Capital/Financial Assets. The poor in general have little access to finance, and women in particular have less access than men. Women face gender-specific barriers in accessing financial services, including the lack of collateral (usually land); low levels of literacy, numeracy, and education; and they have less time and cash to undertake the journey to credit institutions. Credit institutions also discriminate against women by complaining of high transactions costs for the very small amounts that women usually demand. Women therefore usually resort to informal sectors for their financial needs. This of course constrains their ability to expand their economic activities.

\section{(c) Social capital assets}

Participation/Voice. Women are consistently under-represented in institutions at the local and national levels. For example, only 10 per cent of the members of the National Assembly elected in 2002 were women. This was actually an improvement from the 5 per cent in the previous assembly. Representation at the local councils is about the same. Endeley and Sikod (2005) found that among representatives of the twenty-seven villages in the rural areas of the Central and Southern Provinces they studied, only two were women.

Power gaps are also evident within the household, and have implications both for economic decision-making and resource allocation, and in the area of fertility and contraceptive use. Spousal communication is positively associated with contraceptive use. The ability of women to negotiate decisions that affect fertility depends in part on their access to independent income, and the choices that are created through literacy, numeracy and formal education.

Human capital assets have to do with education and health. Although over the past thirty years girls have made more rapid strides than boys to lower the gap in education, the improvements have not benefited the rural poor as much. This is because of the social and cultural roles that determine female participation in education. Domestic chores, especially fetching fuel and water, baby sitting, working on the farm and early marriages are factors limiting rural girls' access to schooling.

Direct productive assets have to do with land, labour and capital/financial assets. Just about all rural women rely on land and land-based resources for their livelihood. Unfortunately, the rights to land and resources are firmly embedded in complex socio-economic, cultural, and political structures that give women only use rights. This tends to accentuate the poverty situation of these women and their families. As they cannot invest in the land, its productivity remains low. 


\section{Conclusions}

It is clear that changes are occurring in women's economic status, and these changes are impacting their decision-making power within the household. The intra-household relationships are being reshaped and gender roles within the household redefined. Nevertheless, men are still the heads of households and the major decision-makers. Women who are more involved in incomeearning activities participate more in decision-making within the household than those who are mostly involved only in household consumption activities. Women with some income-earning power are consulted more often by their husbands, especially on issues that require their (women's) financial contribution. What this implies is that the woman's earning power is important to her ability to bargain with the husband over issues in the household: it is a way of taking away some of the powers of the man.

In spite of this progress, left on their own, empowerment would be a very slow process for women. There is a need for government policy to integrate women-empowering activities into various projects and programmes, and to facilitate their access to labour-augmenting resources (finance, technology, etc). Although women's empowerment is one of the Millennium Development Goals, Cameroon has been very slow in moving the process forward. According to UNDP Cameroon Office (MDG Progress 2003), it seems unlikely, given the progress made so far, that Cameroon will meet the deadline.

The creation of a Ministry for Women's Affairs, which together with the Ministry of Social Affairs, is actively involved with issues related to gender equality is seen as an attempt by the government to tackle the problem of gender equality. At the international level, Cameroon has ratified a number of international conventions and instruments related to human rights, one of which is the Convention on the Elimination of all Forms of Discrimination against Women (CEDAW), signed on the 6 June and ratified on the $23 \mathrm{Au}-$ gust, 1994.

The incentive system influences effort. It is necessary to have an environment that creates incentives for economic agents to contribute to development. Women have the capabilities to contribute like men in various capacities. If the reward system is one that discriminates, then the output of women may not be optimal.

\section{References}

Blackden, Mark and Chita Bhanu, 1998, 'Gender, Growth and Poverty Reduction in Sub-Sahara Africa', SPA Report, Executive Summary, Washington, The World Bank. 
Department of National Accounting and Statistics, 1997, 'Enquête Camerounaise auprès des Ménages (ECAM) Volume II: Resultats’, Ministry of the Economy and Finance, Republic of Cameroon, December.

Endeley, J. B., and Fondo Sikod, 2005, 'The Impact of the Chad-Cameroon Oil Pipeline Operations on Gender Relations, Land Resources and Community Livelihood', University of Buea, Unpublished Research Report.

Fonchingong, C., 1999, 'Structural Adjustment, Women and Agriculture in Cameroon', in Gender and Development, vol. 7 (3), pp. 73-79, Oxford: Oxfam. Fonjong, L., 2001, 'Fostering Women's Participation in Development through Non-Governmental Efforts in Cameroon', The Geographical Journal of the Royal Geographical Society, vol.167 (3), pp. 223-234.

Kabeer, Naila, 2003, 'Gender Mainstreaming in Poverty Eradication and the Millennium Development Goals. A Handbook for Policy-makers and other Stakeholders', London: Commonwealth Secretariat.

Moser, C. and K. Levy, 1986, A Theory and Method of Gender Planning - Meeting Women's Practical and Strategic Needs.

Ngome, Angella N., 2003, ‘Gender Division of Labour and Women’s DecisionMaking Power in Rural Households: The Case of Mbalangi, Ediki and Mabonji Villages of Meme Division', Unpublished Masters Thesis, University of Buea, Department of Women and Gender Studies.

Tchoungui, R., Steve Gartlan, J. A. Mope Simo, Fondo Sikod, Augustin Youmbi, Michel Ngatsana and James Winpenny, 1996, 'Structural Adjustment, the Environment, and Sustainable Development: Case Study for Cameroon', in David Reed, ed., Structural Adjustment, the Environment, and Sustainable Development, London: Earthscan.

UNDP Cameroon Office, 2002, The Republic of Cameroon. Country Report: Millennium Development Goals Progress, Yaoundé.

UNDP Cameroon Office, 2003, The Republic of Cameroon. MDGs Progress Report at Provincial Level, Yaoundé.

Zafiris, Tzannatos, 1998, 'Women and Labour Market Changes in the Global Economy: Growth Helps, Inequalities Hurt and Public Policy Matters', SP Discussion Paper No. 9808, Washington, The World Bank. 